\title{
$N$-(4-bromophenethyl) Caffeamide Protects Skin from UVB-Induced Inflammation Through MAPK/IL-6/NF-KB-Dependent Signaling in Human Skin Fibroblasts and Hairless Mouse Skin
}

\author{
Yueh-Hsiung Kuo ${ }^{1,2,+} \mathbb{1}$, Po-Yuan Wu ${ }^{3,4, \dagger}$, Chien-Wen Chen ${ }^{5}$, Ping Lin ${ }^{5}$, Kuo-Ching Wen ${ }^{5}$, \\ Chien-Yih Lin $^{2}$ and Hsiu-Mei Chiang ${ }^{5, *}$ \\ 1 Department of Chinese Pharmaceutical Sciences and Chinese Medicine Resources, China Medical University, \\ Taichung 404, Taiwan; kuoyh@mail.cmu.edu.tw \\ 2 Department of Biotechnology, Asia University, Taichung 413, Taiwan; yihlin@asia.edu.tw \\ 3 Department of Dermatology, China Medical University Hospital, Taichung 404, Taiwan; \\ wu.poyuan@gmail.com \\ 4 School of Medicine, China Medical University, Taichung 404, Taiwan \\ 5 Department of Cosmeceutics, China Medical University, Taichung 404, Taiwan; \\ walnut0727@hotmail.com (C.-W.C.); a505351@hotmail.com (P.L.); kcwen0412@gmail.com (K.-C.W.) \\ * Correspondence: hmchiang@mail.cmu.edu.tw; Tel.: +886-4-22-053-366 (ext. 5302); Fax: +886-4-22-078-083 \\ $\dagger$ These two authors contribute equally to this work.
}

Received: 4 August 2017; Accepted: 26 September 2017; Published: 29 September 2017

\begin{abstract}
Long-term exposure to ultraviolet (UV) irradiation causes skin inflammation and aging. $\mathrm{N}$-(4-bromophenethyl) caffeamide $(\mathrm{K} 36 \mathrm{H})$ possesses antioxidant and antimelanogenic properties. The present study investigated the effects of $\mathrm{K} 36 \mathrm{H}$ on UVB-induced skin inflammation in human skin fibroblasts and hairless mice and evaluated the underlying mechanisms. The in vitro results indicated that $\mathrm{K} 36 \mathrm{H}$ reduced UVB-induced mitogen-activated protein kinase (MAP kinase) expression. Furthermore, $\mathrm{K} 36 \mathrm{H}$ treatment reduced cyclooxygenase-2 (COX-2) and inducible nitric oxide synthase (iNOS) protein expression in UVB-irradiated fibroblasts by regulating I $\kappa \mathrm{B}$ and nuclear factor-kappa $\mathrm{B}$ (NF-KB) expression. In the animal study, topically applied $\mathrm{K} 36 \mathrm{H}$ markedly reduced inflammation and skin thickness and prevented photodamage to the skin of hairless mice. In addition, $\mathrm{K} 36 \mathrm{H}$ inhibited the levels of UV-upregulated inflammation-related proteins levels such as IL-1, iNOS, and NF- $\kappa B$ in the dermis of hairless mice. Our findings demonstrated the antioxidant and anti-inflammatory properties of $\mathrm{K} 36 \mathrm{H}$ in human skin fibroblasts and hairless mice. Therefore, $\mathrm{K} 36 \mathrm{H}$ can be developed as an antiphotodamage and antiphotoinflammation agent.
\end{abstract}

Keywords: N-(4-bromophenethyl) caffeamide; photoinflammation; propolis; IL-6; NF- $\mathrm{kB}$

\section{Introduction}

Exposure to sunlight can cause oxidative stress and inflammation, resulting in melanogenesis and mutations in skin cells; furthermore, sun exposure can result in skin disorders and cancer [1]. Several studies have indicated that both ultraviolet (UV) A and UVB can cause skin photodamage by stimulating reactive oxygen species (ROS) generation, activating downstream signaling and inflammatory cytokine formation [2]. These cytokines subsequently activate mitogen-activated protein (MAP) kinase signaling and modulate downstream transcription factors, resulting in an inflammatory response [3]. Nuclear factor- $\mathrm{kB}(\mathrm{NF}-\mathrm{kB})$ is a transcription factor that modulates the gene expression of various proinflammatory factors, chemokines, and growth factors. NF- $\kappa B$ and IkB exist as an inactive complex in the cytoplasm. Some proinflammatory factors and MAP kinases activate IкB kinase, 


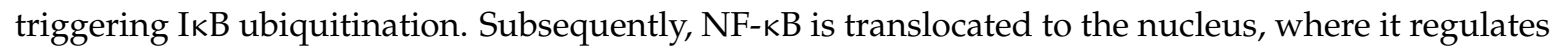
inflammation-related gene transcription and protein expression, leading to inflammation and erythema of the skin $[4,5]$. Furthermore, UV irradiation leads to the generation of ROS that attack biomembrane lipids, increase prostaglandin E2 and nitric oxide secretion, and upregulate prostaglandins, interleukins (ILs), and other cytokines, causing inflammation of the skin [6-8]. In addition, MAP kinases directly activate NF- $\mathrm{KB}$ and promote the translocation of these transcription factors to the nucleus, causing skin inflammation and related skin disorders $[7,9]$.

Materials with antioxidant and anti-inflammatory properties can be used to prevent premature skin aging [10-12]. N-(4-bromophenethyl) caffeamide (K36H, also named EK5, Figure 1) is a caffeic acid phenethyl ester (CAPE) derivative present in propolis. Previous studies have reported that CAPE possesses antioxidant, anti-inflammatory, antiviral, anticarcinogenic, and immunomodulatory properties $[13,14]$. Our previous studies revealed a caffeamide derivative with antiphotoaging properties $[15,16]$. $\mathrm{K} 36 \mathrm{H}$ was discovered to inhibit melanogenesis and tyrosinase activity in B16F0 cells [17]. In addition, $\mathrm{K} 36 \mathrm{H}$ downregulated NF- $\mathrm{KB}$ signaling in human monocytic cells and therefore exhibited anti-inflammatory properties [13].

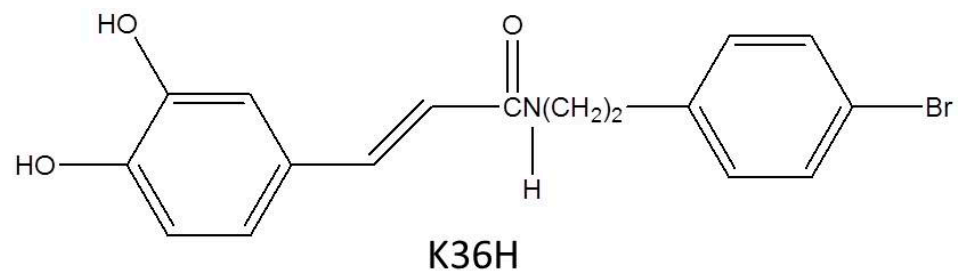

Figure 1. The structure of $N$-(4-bromophenethyl) caffeamide $(\mathrm{K} 36 \mathrm{H})$.

UV light exposure induces skin damage. UVB irradiation is mainly responsible for severe damage such as sunburn, skin damage, and skin cancer [18]. UVA penetrates deeper into the skin than UVB. UVA is not directly absorbed by biological targets and can cause skin and tissue damage [19]. Although UVB radiation only constitutes approximately $5 \%$ of the total solar UV irradiation, it can cross the entire epidermis layer and penetrate the dermis compartment of human skin and has been reported to be a major cause of skin inflammation and photodamage [20]. Because no study has investigated whether $\mathrm{K} 36 \mathrm{H}$ ameliorates skin inflammation and UVB-induced premature skin aging, we examined the antiphotodamage effects of $\mathrm{K} 36 \mathrm{H}$ and the underlying mechanisms in human Hs68 cells by using an animal model.

\section{Results}

\subsection{Effect of $\mathrm{K} 36 \mathrm{H}$ on Cytotoxicity}

Hs68 cells were treated with $5-50 \mu \mathrm{M} \mathrm{K} 36 \mathrm{H}$ for $24 \mathrm{~h}$, and cell viability was measured using MTT assay. The survival rate of Hs68 cells treated with $50 \mu \mathrm{M} \mathrm{K} 36 \mathrm{H}$ was $86.1 \pm 1.4 \%$ (Figure 2). Cell viability of $\geq 80 \%$ has been reported to be the criterion for cytotoxicity [21,22]. Therefore, the survival rate indicated that $\mathrm{K} 36 \mathrm{H}(5-50 \mu \mathrm{M})$ was not toxic to Hs68 cells. 


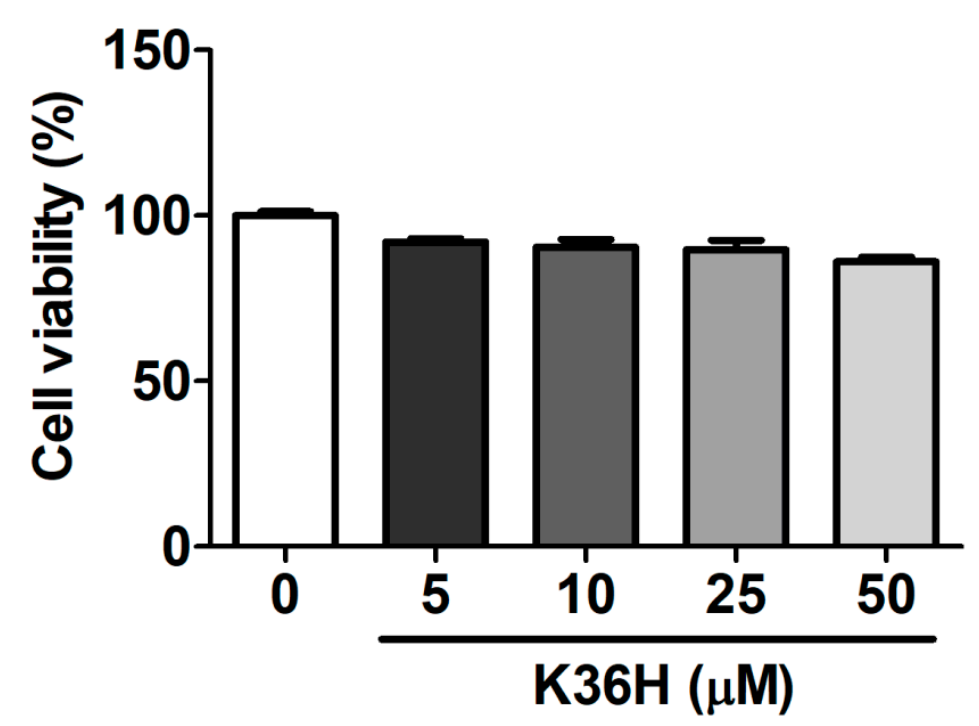

Figure 2. Human skin fibroblast viability (\%) after treatment with $\mathrm{K} 36 \mathrm{H}$. $\mathrm{K} 36 \mathrm{H}$ was not toxic to Hs68 cells.

\subsection{Antioxidant Properties of $\mathrm{K} 36 \mathrm{H}$}

\subsubsection{K36H Scavenged DPPH Radicals}

The DPPH radical scavenging activity assay is generally employed as a model to evaluate the antioxidant properties of target drugs for free radical scavenging [23]. $\mathrm{K} 36 \mathrm{H}$ exhibited a scavenging activity of $62.1 \pm 2.9 \%$ and $96.6 \pm 0.4 \%$ at 25 and $50 \mu \mathrm{M}$, respectively. The scavenging activity of $\mathrm{K} 36 \mathrm{H}$ was superior to that of equal concentrations of ascorbic acid (Figure 3). The $\mathrm{SC}_{50}$ of $\mathrm{K} 36 \mathrm{H}$ for DPPH scavenging activity was $20.0 \pm 1.0 \mu \mathrm{M}$.

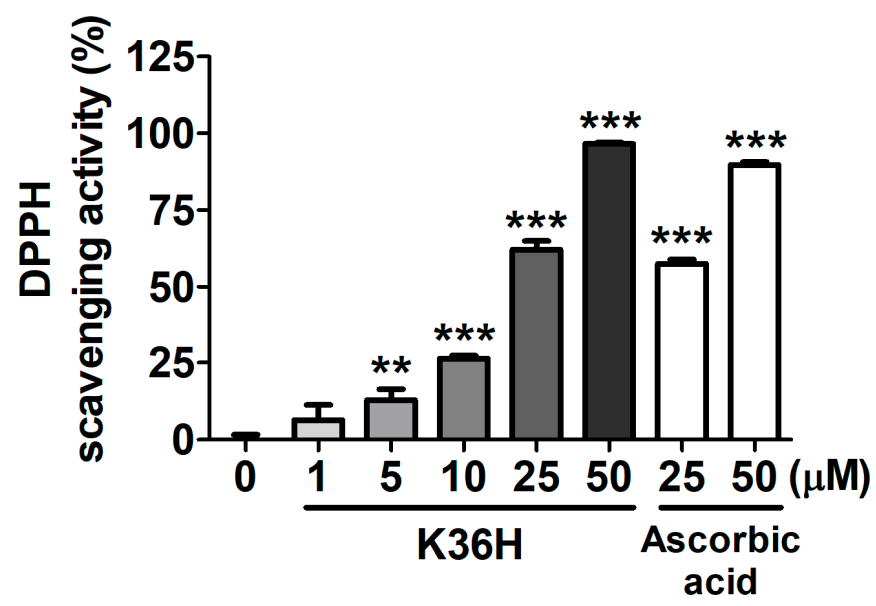

Figure 3. 1,1-Diphenyl-2-picrylhydrazyl (DPPH) radical scavenging activity of $\mathrm{K} 36 \mathrm{H}$. Significant difference versus nontreatment group: ${ }^{* *}, p<0.01 ;{ }^{* *}, p<0.001$.

\subsection{2. $\mathrm{K} 36 \mathrm{H}$ Alleviated UVB-Induced ROS Generation in Hs68 Cells}

UV-induced ROS generation can trigger skin photoaging-related gene and protein expression and downstream signal transduction, causing oxidative stress in human skin cells. In this study, treatment with $80 \mathrm{~mJ} / \mathrm{cm}^{2}$ UVB considerably increased ROS generation in Hs68 cells, whereas treatment with UVB and 5, 10, and $25 \mu \mathrm{M} \mathrm{K} 36 \mathrm{H}$ resulted in $80 \%, 90 \%$, and $100.0 \%$ less ROS formation, respectively (Figure 4). Ascorbic acid inhibited the intracellular ROS generation induced by UVB. Therefore, K36H alleviated UVB-induced damage by scavenging ROS in the Hs68 fibroblasts. 


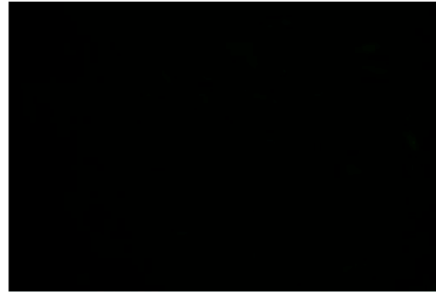

(A) Control

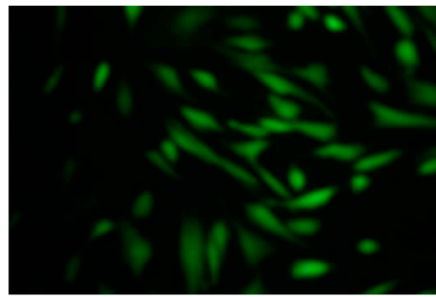

(B) UVB

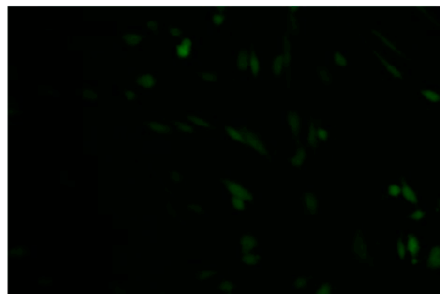

(C) UVB + Ascorbic acid $(25 \mu \mathrm{M})$

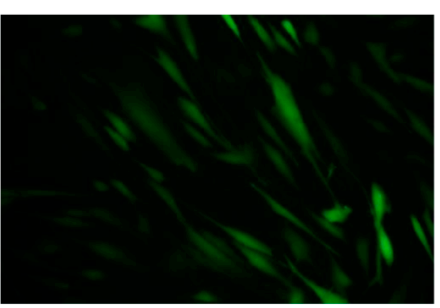

(D) UVB + K36H (5 $\mu \mathrm{M})$

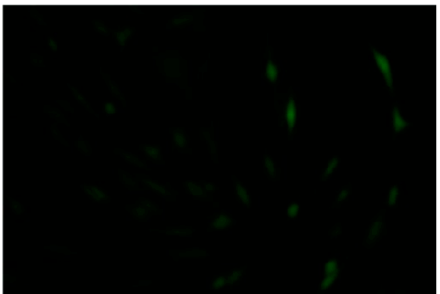

(E) UVB + K36H (10 $\mu \mathrm{M})$

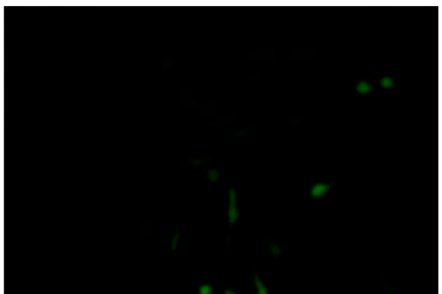

(F) UVB + K36H $(25 \mu \mathrm{M})$

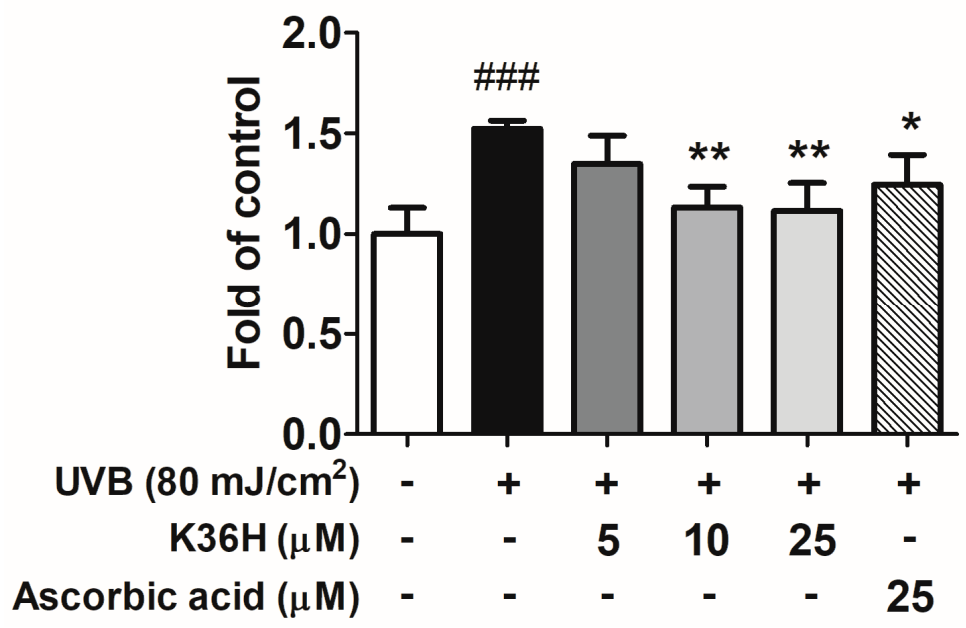

Figure 4. Intracellular reactive oxygen species (ROS) level measurement with $2^{\prime}, 7^{\prime}$-dichlorofluorescin diacetate (DCFDA) reagent after $\mathrm{K} 36 \mathrm{H}$ treatment in ultraviolet (UV) B-irradiated human fibroblasts. Ascorbic acid was used as positive control. Significant difference versus nonirradiation group: $\# \#, p<0.001$. Significant difference versus nontreatment group: ${ }^{*}, p<0.05 ;{ }^{* *}, p<0.01$.

\subsection{K36H Inhibited MAP Kinase Expression}

UVB irradiation induced the phosphorylation of MAP kinases, triggering downstream signal transduction and resulting in the regulation of the MMP expression level. After UVB irradiation, the phosphorylation of ERK increased 1.3-fold compared with the control group, and this effect was diminished significantly by $\mathrm{K} 36 \mathrm{H}$ treatment at $>10 \mu \mathrm{M}$ concentrations for $24 \mathrm{~h}$. The results for JNK and p-38 phosphorylation were similar to those for ERK. K36H treatment at $>10 \mu \mathrm{M}$ concentrations reduced UVB-induced JNK phosphorylation and p-38 expression (Figure 5). 

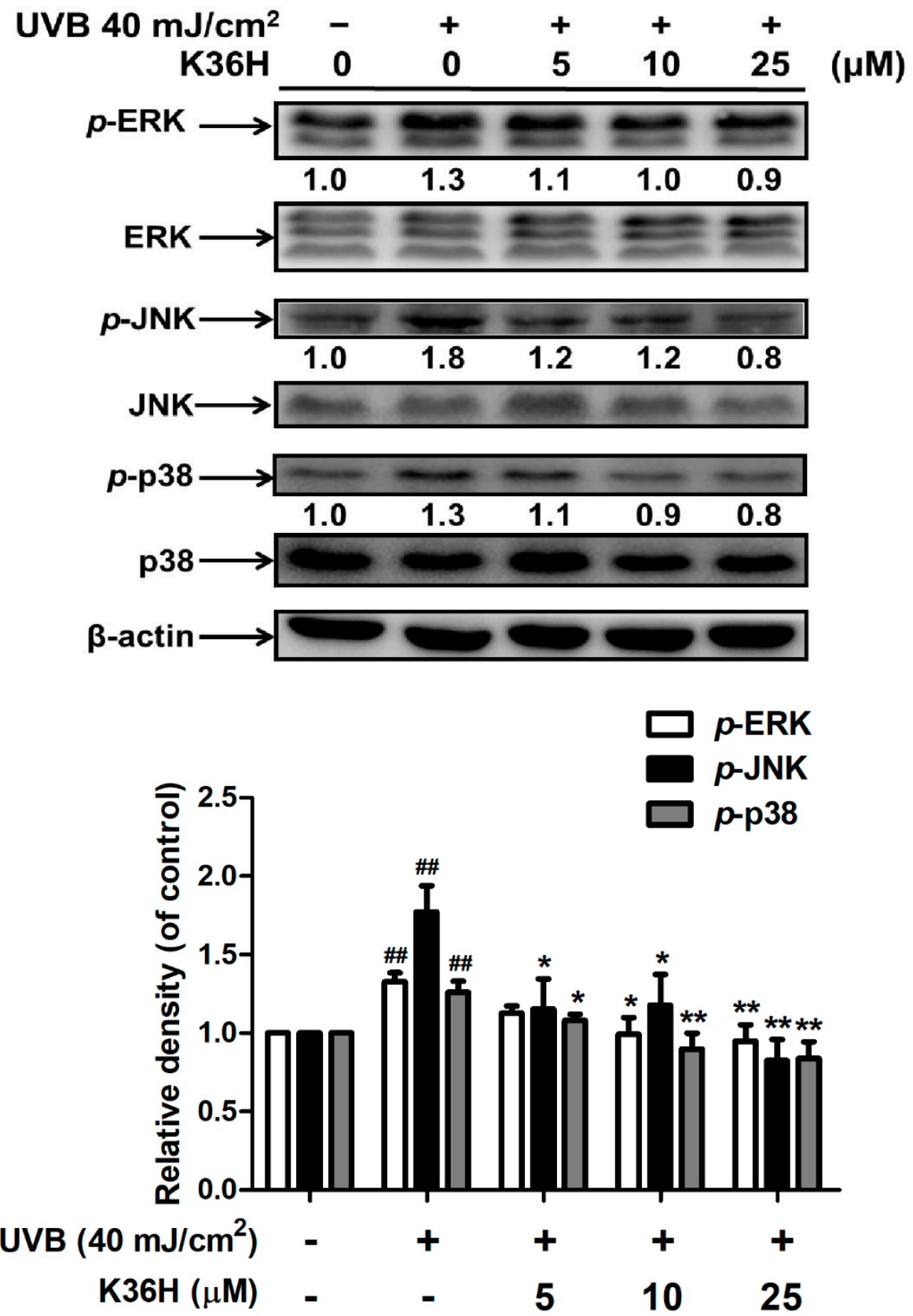

Figure 5. Effect of $\mathrm{K} 36 \mathrm{H}$ on the UVB-induced phosphorylation of mitogen-activated protein (MAP) kinases in human fibroblasts. Significant difference versus nonirradiation group: ${ }^{\#}, p<0.01$. Significant difference versus nontreatment group: ${ }^{*}, p<0.05 ;{ }^{* *}, p<0.01$.

\subsection{K36H Alleviated UVB-Induced Inflammation in Human Skin Fibroblasts}

\subsubsection{K36H Reduced UVB-Induced iNOS and COX-2 Overexpression}

Figure 6 illustrates the effects of $\mathrm{K} 36 \mathrm{H}$ treatment on iNOS expression in $\mathrm{Hs} 68$ cells. $\mathrm{K} 36 \mathrm{H}$ dose-dependently inhibited UVB-induced iNOS overexpression. UVB irradiation increased iNOS expression (by 1.4-fold compared with the control group); however, $24 \mathrm{~h}$ treatment with $5 \mu \mathrm{M} \mathrm{K} 36 \mathrm{H}$ significantly reduced iNOS expression by 0.9 -fold compared with the control group.

UVB irradiation increased COX-2 expression in Hs68 cells by 2.0-fold compared with the control group (Figure 5). Furthermore, $\mathrm{K} 36 \mathrm{H}$ treatment $(5-25 \mu \mathrm{M})$ dose-dependently reduced UVB-induced COX-2 expression levels; this effect was significant at $>10 \mu \mathrm{M}$ concentrations (Figure 6). 


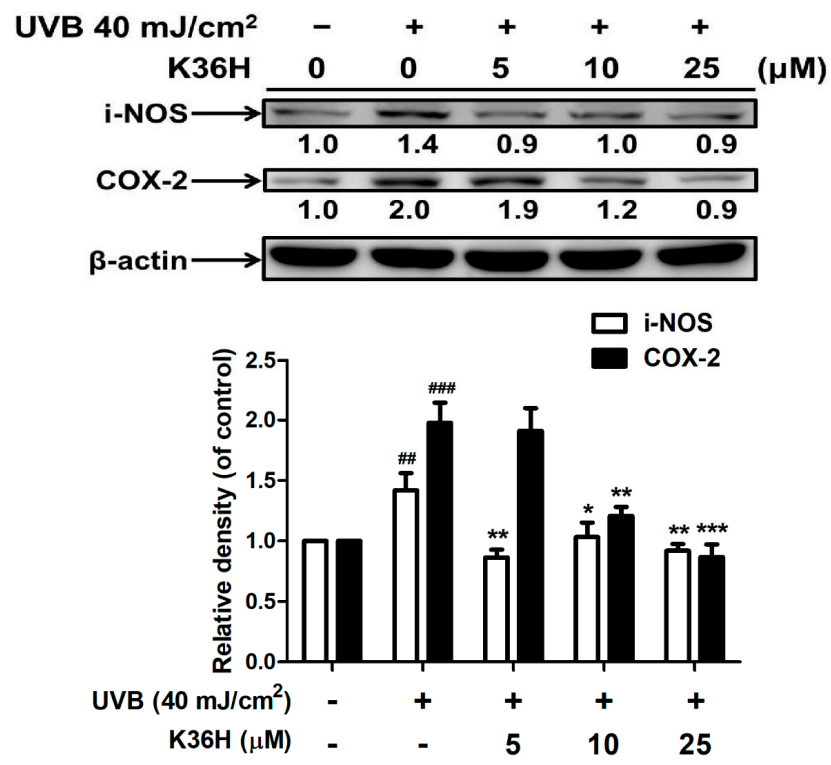

Figure 6. UVB-induced inducible nitric oxide synthase (iNOS) and COX-2 expression levels in human fibroblasts. Significant difference versus nonirradiation group: ${ }^{\#}, p<0.01$; ${ }^{\# \#}, p<0.001$. Significant difference versus nontreatment group: ${ }^{*}, p<0.05 ;{ }^{* *}, p<0.01 ;{ }^{* * *}, p<0.001$.

\subsubsection{K36H Modulated IкB/NF-кB Transduction}

The results of Western blotting indicated that UVB irradiation suppressed IkB $\alpha$ expression but increased p-IкB $\alpha$ expression. Treatment with $5 \mu \mathrm{M} \mathrm{K36H}$ for $24 \mathrm{~h}$ increased $\mathrm{p}-\mathrm{I} \kappa \mathrm{B} \alpha$ expression by 1.2-fold but significantly reduced $\mathrm{p}$-IКB $\alpha$ expression by 0.9 -fold compared with the control group (Figure 7). In addition, treatment with $10 \mu \mathrm{M} \mathrm{K36H}$ significantly enhanced I $\mathrm{B} \alpha$ expression (Figure 7). $\mathrm{I} \kappa \mathrm{B} \alpha$ is degraded because of ubiquitination; thus, NF- $\mathrm{KB}$ is translocated from the cytoplasm to the nucleus, causing an inflammatory response.

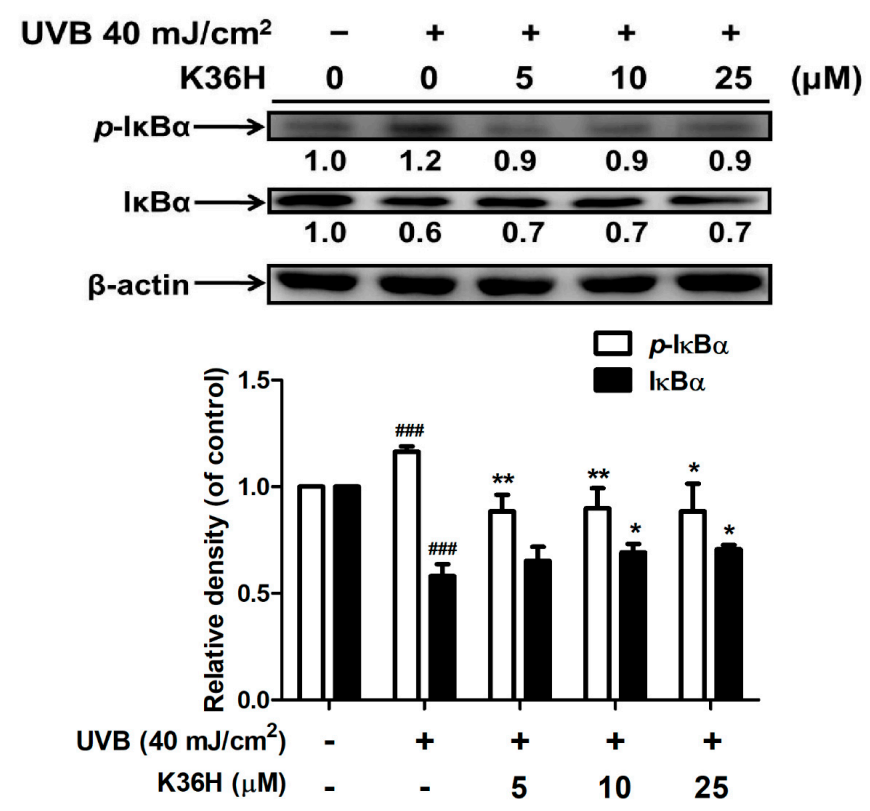

Figure 7. Effect of $\mathrm{K} 36 \mathrm{H}$ on UVB-induced $\mathrm{p}-\mathrm{I} \kappa \mathrm{B} \alpha$ and $\mathrm{I} \kappa \mathrm{B} \alpha$ expression in human fibroblasts. Significant difference versus nonirradiation group: ${ }^{\# \#}, p<0.001$. Significant difference versus nontreatment group: ${ }^{*}, p<0.05 ;{ }^{* *}, p<0.01$. 
In this study, immunohistochemical staining of NF- $\kappa B$ in the fibroblasts was applied to assay the activation of NF- $\mathrm{kB}$. As demonstrated in Figure 8, UVB irradiation triggered NF- $\mathrm{B}$ translocation to the nucleus, whereas $\mathrm{K} 36 \mathrm{H}$ treatment inhibited this effect. $\mathrm{K} 36 \mathrm{H}$ inhibited the ubiquitination of $\mathrm{I} \kappa \mathrm{B} \alpha$, thus preventing the activation of NF-kB and skin photodamage.

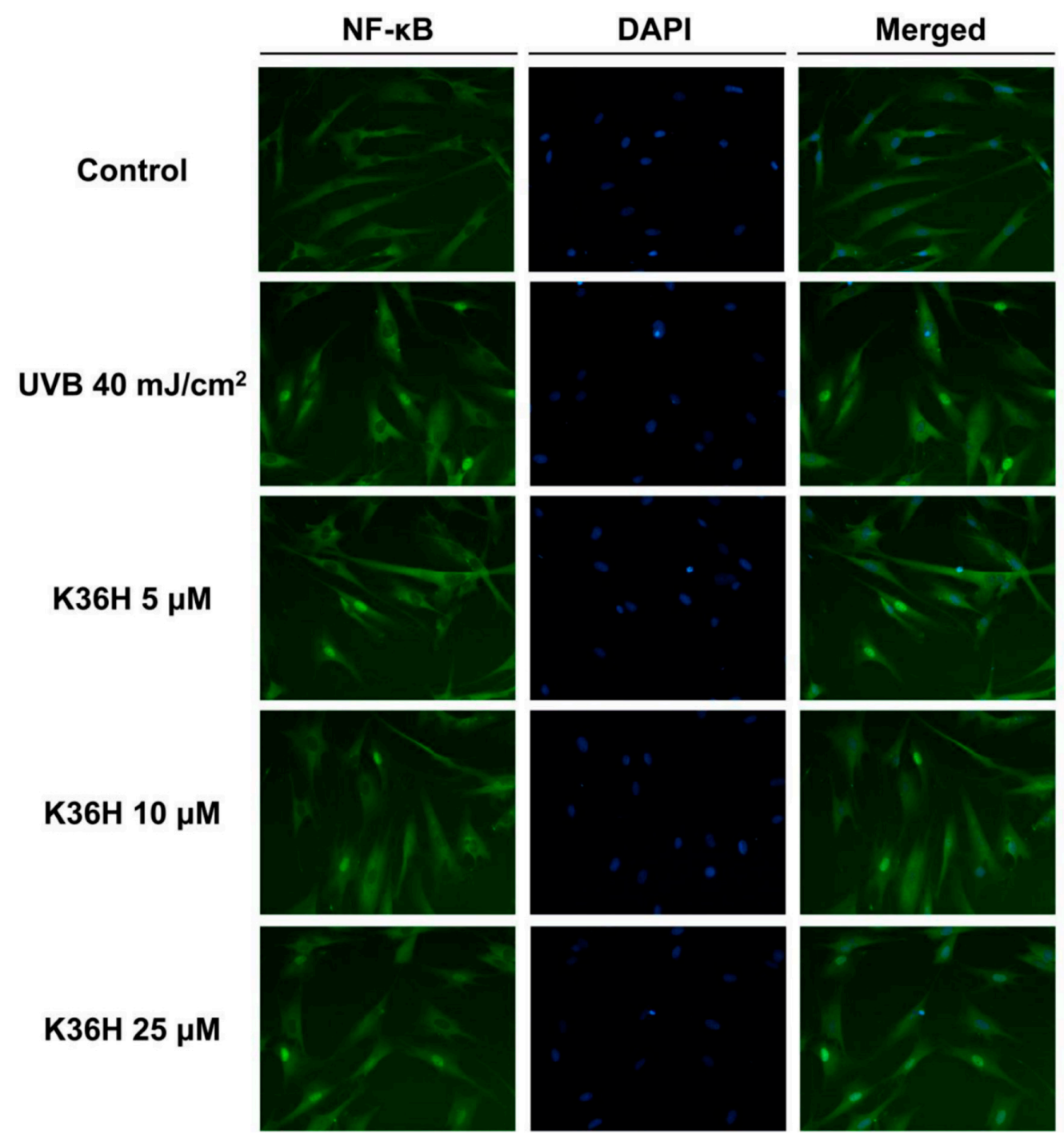

Figure 8. Effect of K36H on UVB-induced activation of NF-кB P65 in human fibroblasts. K36H inhibited the UVB-induced translocation of NF-kB into the nucleus.

\subsection{Effects of K36H on UVB-Induced Skin Inflammation in Hairless Mice}

UVB exposure resulted in skin inflammation and elevated $a^{*}$ values of the skin. In the present study, UVB increased the $\mathrm{a}^{*}$ values, whereas $\mathrm{K} 36 \mathrm{H}$ reduced the $\mathrm{a}^{*}$ values without significant differences (data not shown).

Transepidermal water loss (TEWL) is an indicator of skin barrier function. UVB exposure disturbed the skin barrier function, thereby increasing TEWL in mice skin. UV exposure caused significant changes in the TEWL of hairless mice dorsal skin. However, TEWL did not exhibit significant differences after $\mathrm{K} 36 \mathrm{H}$ application on the dorsal skin of hairless mice for 12 weeks (Figure 9). These results suggested that $\mathrm{K} 36 \mathrm{H}$ did not exhibit skin toxicity or disturb the skin barrier function. 


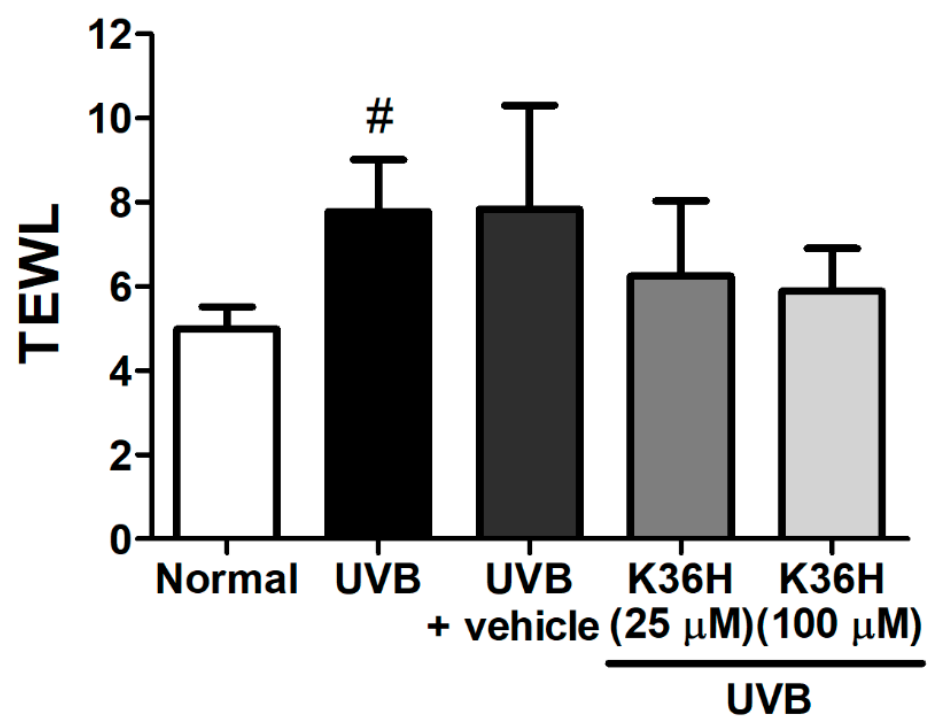

Figure 9. Effect of $\mathrm{K} 36 \mathrm{H}$ on transepidermal water loss (TEWL) in chronic UVB-irradiated hairless mice at 12 weeks.

\subsection{K36H Reduced UVB-Induced Epidermal Hyperplasia in Hairless Mouse Skin}

The epidermal thickness of UVB-irradiated mice increased significantly after 12 weeks (Figures 10 and 11). However, $\mathrm{K} 36 \mathrm{H}$ application on the dorsal skin reduced this UVB-induced epidermal hyperplasia (Figures 10 and 11).

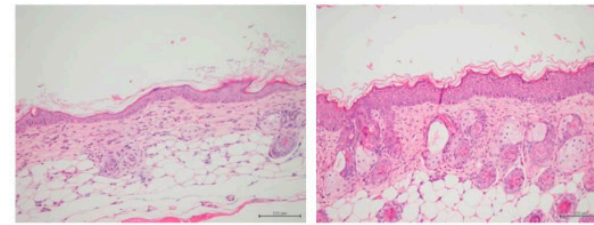

(A) Normal
(B) UVB

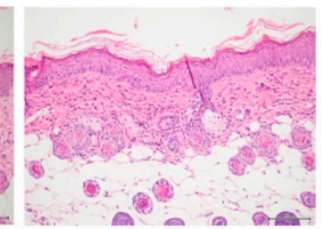

(C) UVB + vehicle

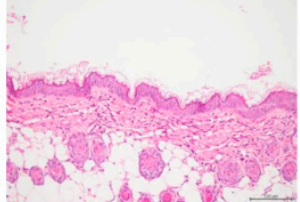

(D) UVB + K36H

$(25 \mu \mathrm{M})$

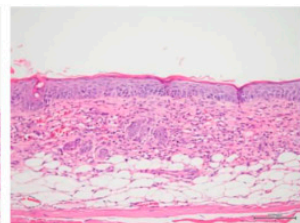

(E) UVB + K36H $(100 \mu \mathrm{M})$

Figure 10. Light micrographs of histological sections stained with hematoxylin and eosin (H\&E) in hairless mice.

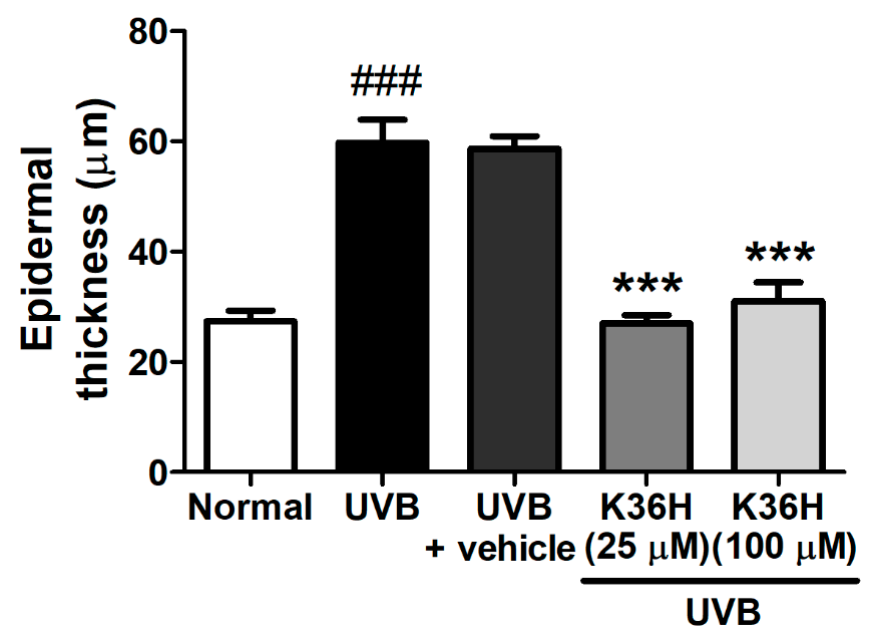

Figure 11. Effect of $\mathrm{K} 36 \mathrm{H}$ on the epidermal thickness in UVB-exposed hairless mice. Significant difference versus normal group: ${ }^{\# \# \#} p<0.001$. Significant difference versus UVB group: ${ }^{* * *} p<0.001$. 


\subsection{Effects of K36H on Inflammation-Related Proteins in UVB-Exposed Mice Skin}

Figures 12-14 indicated that the expressions of IL-6, iNOS, and NF- $\mathrm{kB}$ were increased after 12-weeks UVB exposure; $\mathrm{K} 36 \mathrm{H}$ treatment decreased the expression of these proteins. The results indicated that topically applied $\mathrm{K} 36 \mathrm{H}$ inhibited UVB irradiation-induced inflammatory protein expression. Therefore, $\mathrm{K} 36 \mathrm{H}$ inhibited UVB-induced inflammation and collagen degradation, exhibiting antiphotodamage properties.

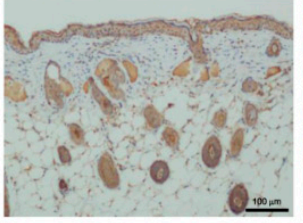

(A) Normal

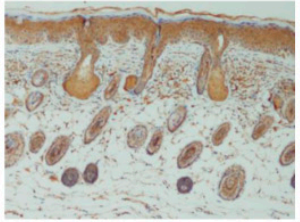

(B) UVB

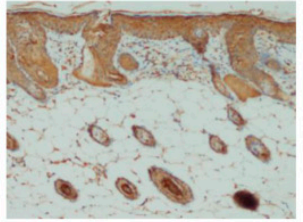

(C) UVB + vehicle

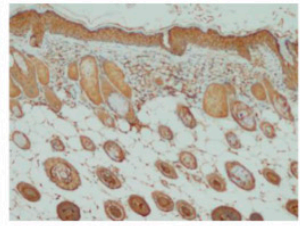

(D) UVB + K36H

$(25 \mu \mathrm{M})$

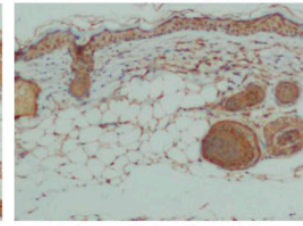

(E) UVB + K36H $(100 \mu \mathrm{M})$

Figure 12. Immunohistochemical staining of IL-6 expression on mice skin slices. K36H inhibited UVB-induced IL-6 overexpression in mice skin.

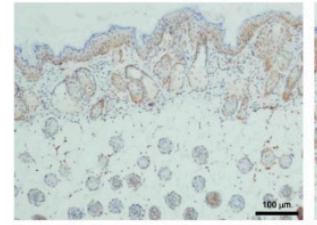

(A) Normal

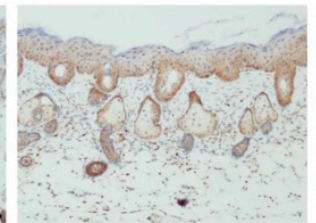

(B) UVB

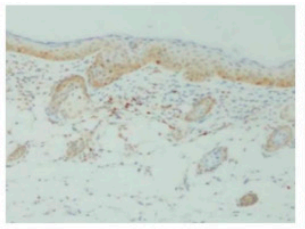

(C) UVB + vehicle

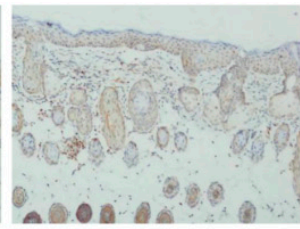

(D) UVB + K36H

$(25 \mu \mathrm{M})$

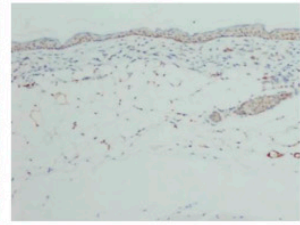

(E) UVB + K36H $(100 \mu \mathrm{M})$

Figure 13. Immunohistochemical staining of iNOS expression on mice skin slices. $\mathrm{K} 36 \mathrm{H}$ inhibited UVB-induced iNOS overexpression in mice skin.

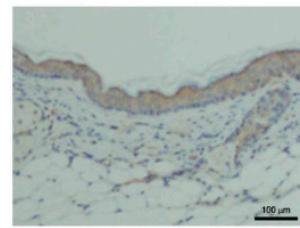

(A) Normal

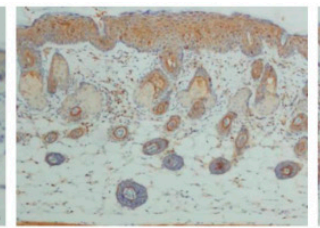

(B) UVB

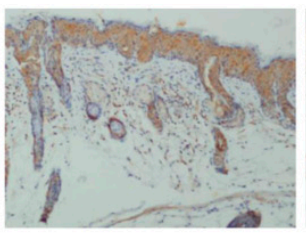

(C) UVB + vehicle

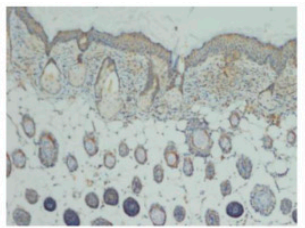

(D) UVB + K36H

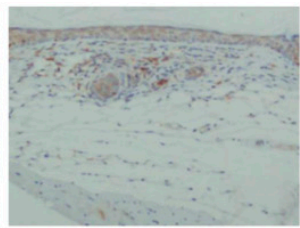

(E) UVB + K36H $(100 \mu \mathrm{M})$

Figure 14. Immunohistochemical staining of NF- $\kappa B$ expression on mice skin slices. $\mathrm{K} 36 \mathrm{H}$ inhibited UVB-induced NF-kB overexpression in mice skin.

\section{Discussion}

UV-induced oxidative stress and inflammation cause skin damage and aging. ROS production is initiated through a complex cascade of signal transductions and reactions in the skin. UV exposure increases ROS generation in skin cells, inducing skin damage and lipid peroxidation. Therefore, photodamage prevention strategies involve free radical scavenging and quenching. Furthermore, anti-inflammation agents such as COX and cytokine production inhibitors may prevent skin photodamage [24-26]. Accordingly, antioxidant and anti-inflammatory agents can be applied to alleviate photoaging $[27,28]$. The results of this study indicated that K36H quenches DPPH radicals and reduces UVB-induced ROS generation in Hs68 cells. However, it did not exhibit significant scavenging activity of hydrogen peroxide and ferrous chelating activity. A previous study demonstrated the antioxidant properties of CAPE, and its catechol group may contribute to its antioxidant properties [29]. The catechol groups of caffeamide derivatives are electron donors that terminate free radical activity. 
Exogenous antioxidant application may be an effective strategy to ameliorate ROS-induced skin damage, which is caused by excessive UV exposure [30,31].

UV irradiation leads to ROS generation, which promotes MAP kinase activation and recruits AP-1 to the nucleus and subsequently activates NF- $\mathrm{kB}$ and proinflammatory-related genes and proteins [32, 33]. The generation of cytokines, such as IL-1 and IL-6, mediates UV-induced skin inflammation. UVB exposure activates NF- $k B$, which plays a key role in inflammation that is mediated through the activation of multifunctional cytokines such as IL-6 by binding to the promoter region [34,35]. UVB exposure induces oxidative stress that stimulates MAP kinases and NF- $\mathrm{KB}$, ultimately increasing skin inflammation [36]. Activated NF- $\mathrm{kB}$ can induce MMP expression in dermal fibroblasts, causing skin damage and photoaging [34]. A study reported that kirenol reduced the UVB-induced phosphorylation of ERK, JNK, and p38 and inhibited the expression of inflammatory mediators (NF-KB, IL-6, and IL-8) to prevent UVB-induced inflammation and photodamage [36].

UV exposure causes inflammatory changes in the skin, such as erythema and hyperpigmentation, and the production of inflammatory cytokines and proteins that result in skin appearance and vascular responses [37]. In vivo UVB exposure of murine skin caused IL-1 production in epidermal cells, which was detected in UV-exposed human skin [38]. The secretion of these proinflammatory cytokines plays a pivotal role in the recruitment and activation of inflammatory cells, resulting in UVB-induced skin damage [29].

UV irradiation can cause NF- $\mathrm{B}$ translocation, thereby inducing MMP production for collagen degradation in the dermis. The antioxidant activity of $\mathrm{K} 36 \mathrm{H}$ may contribute to its inhibitory effect against NF- $\kappa B$ activation. $\mathrm{K} 36 \mathrm{H}$ may prevent I $\kappa \mathrm{B}$ dissociation from the complex with NF- $\kappa \mathrm{B}$. Furthermore, NF- $\mathrm{KB}$ modulates the protein expression and gene transcription of COX-2 and iNOS, leading to skin inflammation [30,32]. The present study demonstrated that $\mathrm{K} 36 \mathrm{H}$ reduced UVB-induced COX-2 and iNOS protein expression in hairless mice. In addition, $\mathrm{K} 36 \mathrm{H}$ inhibited the translocation of $\mathrm{NF}-\mathrm{kB}$ to the nucleus in skin fibroblasts. $\mathrm{K} 36 \mathrm{H}$ also inhibited the UVB-induced overexpression of IL-6, iNOS, and NF-kB in hairless mice, protecting them from UV-induced skin damage.

\section{Materials and Methods}

\subsection{Materials}

Thiazolyl blue tetrazolium bromide (MTT) and IGEPAL CA-630 were purchased from the USB Corporation (Cleveland, OH, USA). The medium, serum, and reagents for cell culture were obtained from Invitrogen Co. (Carlsbad, CA, USA). Other reagents used in this study were of reagent grade and were purchased from Sigma-Aldrich (St. Louis, MO, USA). K36H was supplied by one of the authors, Professor Kuo, and was synthesized as described previously [13].

\subsection{Detecting 1,1-Diphenyl-2-picrylhydrazyl Radical Scavenging Activity}

The 1,1-diphenyl-2-picrylhydrazyl (DPPH) radical scavenging activity of $\mathrm{K} 36 \mathrm{H}$ was measured as described previously [15,39]. The positive control was ascorbic acid. Reaction mixtures containing DPPH prepared in methanol and $2-100 \mu \mathrm{M} \mathrm{K36H}$ were incubated at room temperature. Thereafter, the absorbance at $492 \mathrm{~nm}$ was detected on a microplate reader (Tecan, Untersbergstraße, Austria).

\subsection{Fibroblast Culture and UV Exposure}

Human foreskin fibroblasts (Hs68) were incubated in Dulbecco's modified Eagle's medium containing 10\% fetal bovine serum and $100 \mathrm{U} / \mathrm{mL}$ penicillin and streptomycin. The cells were grown in an incubator at $37^{\circ} \mathrm{C}$ with $5 \% \mathrm{CO}_{2}$. The cells were exposed to UVB in a UV crosslinker ( $302 \mathrm{~nm} \mathrm{UV}$, $5 \times 8$ watt UV dual bipin discharge type, CL-1000M, UVP, Upland, CA, USA) that delivered a UVB energy of wavelength $302 \mathrm{~nm}$. The UVB dose was $40 \mathrm{~mJ} / \mathrm{cm}^{2}$, and the exposure was approximately $15 \mathrm{~s}$. 


\subsection{Intracellular ROS Assay}

The intracellular ROS in the Hs68 cells were detected using the $2^{\prime}, 7^{\prime}$-dichlorofluorescin diacetate (DCFDA) reagent, as previously described [40,41]. Ascorbic acid $(25 \mu \mathrm{M})$ was used as positive control. The fibroblasts were exposed to UVB irradiation and incubated with $5-25 \mu \mathrm{M} \mathrm{K} 36 \mathrm{H}$ for $1 \mathrm{~h}$. Thereafter, DCFDA was added, and the mixture was incubated for $30 \mathrm{~min}$. The fluorescence of the mixture (emission and excitation wavelengths: 488 and $520 \mathrm{~nm}$, respectively) was assayed on an enzyme-linked immunosorbent assay reader (Thermo Electron Corporation, Vantaa, Finland). Images were captured using a fluorescence microscope (Leica DMIL, Heidelberg, Germany).

\subsection{Western Blotting}

The fibroblasts were exposed to UVB irradiation and incubated with 5-25 $\mu \mathrm{M} \mathrm{K36H}$ for 4 or $24 \mathrm{~h}$. After UVB irradiation and $\mathrm{K} 36 \mathrm{H}$ treatment, whole cell protein lysate was obtained for immunoblot analysis through Western blotting, as previously described [16]. The cell lysate was separated using sodium dodecyl sulfate polyacrylamide gel electrophoresis. Blots were blocked for $2 \mathrm{~h}$ with non-fat milk in TBS buffer. The membrane was incubated for $16 \mathrm{~h}$ with specific antibodies. The membranes were washed with TBST for $40 \mathrm{~min}$. The blot was then incubated with the corresponding conjugated anti-immunoglobulin G-horseradish peroxidase (Santa Cruz Biotechnology Inc., Santa Cruz, CA, USA). Immunoreactive proteins were detected using specific antibodies with the enhanced chemiluminescent Western blotting detection system (Amersham, Buckinghamshire, UK), and the densitometric program was used to quantify band densities.

\subsection{Immunofluorescence Staining}

The cells were cultivated on cover slips and incubated with $5-25 \mu \mathrm{M} \mathrm{K} 36 \mathrm{H}$ for $24 \mathrm{~h}$ after UVB exposure, as previously described [15]. The cells were fixed with 4\% paraformaldehyde for $30 \mathrm{~min}$. The cells were incubated with primary and secondary antibodies (Alexa Fluor 488 anti-rabbit IgG, Invitrogen, CA, USA). The cells were counterstained with ProLong® Gold antifade reagent, and images were obtained using a Confocal Spectral Microscope (Leica SP2, Frankfurt am Main, Germany).

\subsection{Animal Study}

The animal study was approved by the Institutional Animal Use and Care Committee of China Medical University, and the protocol number was 100-124-N. All methods were performed in accordance with the relevant guidelines and regulations. Six-week-old female BALB/c hairless mice were purchased from the National Laboratory Animal Center, Taipei, Taiwan. All mice were fed standard chow and kept in a temperature-, humidity-, and light/dark cycle-controlled room.

\subsection{Effect of $\mathrm{K} 36 \mathrm{H}$ on UVB-Induced Skin Inflammation}

Six-week-old female BALB/c hairless mice were randomly divided into the following five groups (six per group): control group, UVB-irradiated group, UVB-irradiated and vehicle-treated group, UVB-irradiated and $25-\mu \mathrm{M}-\mathrm{K} 36 \mathrm{H}$-treated group, and UVB-irradiated and $100-\mu \mathrm{M}-\mathrm{K} 36 \mathrm{H}$-treated group. Mice were exposed to UVB irradiation (302 nm UV, $5 \times 8$ watt UV dual bipin discharge type, CL-1000M, UVP, Upland, CA, USA) three times per week and were treated with $50 \mu \mathrm{L}$ of vehicle (glycerol) or $\mathrm{K} 36 \mathrm{H}$ ( 25 or $100 \mu \mathrm{M}$ ) every day for 12 weeks, as previously described [42]. The UVB dose was $36 \mathrm{~mJ} / \mathrm{cm}^{2} \mathrm{in}$ the first week, $54 \mathrm{~mJ} / \mathrm{cm}^{2}$ in the 2-4 weeks, $72 \mathrm{~mJ} / \mathrm{cm}^{2} 5-7$ weeks, and $108 \mathrm{~mJ} / \mathrm{cm}^{2} 8-10$ weeks [42].

Erythema and transepidermal water loss (TEWL) were measured using an MPA 580 system (Courage + Khazaka electronic GmbH, Cologne, Germany) [28].

\subsection{Immunohistochemical Staining of Skin Slices}

After 12 weeks of treatment, mice were sacrificed, and the dorsal skin samples were excised and fixed in $10 \%$ formaldehyde. The skin slices were stained with hematoxylin and eosin or Masson's 
trichrome. The slices' histopathology was examined using a microscope, and ImageJ software (Wayne Rasband, National Institutes of Health, Bethesda, MD, USA) was used to determine skin thickness. The samples were stained with specific monoclonal anti-mouse antibodies and examined under a microscope [28].

\subsection{Data Analysis}

Numerical data are expressed as mean \pm standard deviation. All measurements in this study are expressed as the averages from at least three independent experiments. The group comparison results were analyzed using the Student's $t$ test or analysis of variance. All differences were statistically significant if $p<0.05$.

\section{Conclusions}

The present study demonstrated that $\mathrm{K} 36 \mathrm{H}$ inhibits UVB-induced skin inflammation by scavenging free radicals, inhibiting intracellular ROS generation, and suppressing overexpression of phosphorylated MAP kinases. In addition, $\mathrm{K} 36 \mathrm{H}$ reduced iNOS and COX-2 expression and modulated the I $\mathrm{B} / \mathrm{NF}-\kappa \mathrm{B}$ pathway, attenuating photodamage to the skin. $\mathrm{K} 36 \mathrm{H}$ ameliorated UV irradiation-induced wrinkle formation in the skin of hairless mice by inhibiting photoinflammation. To further understand the protective effects of $\mathrm{K} 36 \mathrm{H}$ against UV-induced damage, additional experiments on the $\mathrm{K} 36 \mathrm{H}$-mediated prevention of UVA-induced skin damage are required in the future.

Acknowledgments: This work was financially supported by the Ministry of Science and Technology (MOST 104-2320-B-039-006), Taipei; in part by the Taiwan Ministry of Health and Welfare Clinical Trial Center (MOHW106-TDU-B-212-113004) and by China Medical University (CMU102-ASIA-18, CMU103-ASIA-11 and CHM106-5-2). Experiments and data analysis were partly performed at the Medical Research Core Facilities Center, Office of Research \& Development, at China Medical University, Taichung, Taiwan, R.O.C.

Author Contributions: Y.-H.K., C.-Y.L., and H.-M.C. were responsible for study design and the provision of research funding. P.-Y.W. and H.M.C. designed the experiments and provided technical guidance. C.-W.C. and P.L. performed the experimental operation. Y.-H.K., K.-C.W., and H.-M.C. wrote the manuscript. All authors have read and approved the final manuscript.

Conflicts of Interest: The authors declare no conflicts of interest.

\section{References}

1. Lee, C.W.; Na, Y.; Park, N.H.; Kim, H.S.; Ahn, S.M.; Kim, J.W.; Kim, H.K.; Jang, Y.P. Amentoflavone inhibits UVB-induced matrix metalloproteinase-1 expression through the modulation of AP-1 components in normal human fibroblasts. Appl. Biochem. Biotechnol. 2012, 166, 1137-1147. [CrossRef] [PubMed]

2. Portugal-Cohen, M.; Soroka, Y.; Frusic-Zlotkin, M.; Verkhovsky, L.; Bregegere, F.M.; Neuman, R.; Kohen, R.; Milner, Y. Skin organ culture as a model to study oxidative stress, inflammation and structural alterations associated with UVB-induced photodamage. Exp. Dermatol. 2011, 20, 749-755. [CrossRef] [PubMed]

3. Herrlich, P.; Karin, M.; Weiss, C. Supreme EnLIGHTenment: Damage recognition and signaling in the mammalian UV response. Mol. Cell 2008, 29, 279-290. [CrossRef] [PubMed]

4. Nicolaou, A.; Pilkington, S.M.; Rhodes, L.E. Ultraviolet-radiation induced skin inflammation: Dissecting the role of bioactive lipids. Chem. Phys. Lipids 2011, 164, 535-543. [CrossRef] [PubMed]

5. Lindstrom, T.M.; Bennett, P.R. The role of nuclear factor kappa B in human labour. Reproduction 2005, 130, 569-581. [CrossRef] [PubMed]

6. Lopez-Camarillo, C.; Ocampo, E.A.; Casamichana, M.L.; Perez-Plasencia, C.; Alvarez-Sanchez, E.; Marchat, L.A. Protein kinases and transcription factors activation in response to UV-radiation of skin: Implications for carcinogenesis. Int. J. Mol. Sci. 2012, 13, 142-172. [CrossRef] [PubMed]

7. Halliday, G.M. Inflammation, gene mutation and photoimmunosuppression in response to UVR-induced oxidative damage contributes to photocarcinogenesis. Mutat. Res. 2005, 571, 107-120. [CrossRef] [PubMed]

8. Hruza, L.L.; Pentland, A.P. Mechanisms of UV-induced inflammation. J. Investig. Dermatol. 1993, 100, S35-S41. [CrossRef] 
9. Bachelor, M.A.; Bowden, G.T. UVA-mediated activation of signaling pathways involved in skin tumor promotion and progression. Semin. Cancer Biol. 2004, 14, 131-138. [CrossRef] [PubMed]

10. Wu, N.L.; Fang, J.Y.; Chen, M.; Wu, C.J.; Huang, C.C.; Hung, C.F. Chrysin protects epidermal keratinocytes from UVA- and UVB-induced damage. J. Agric. Food Chem. 2011, 59, 8391-8400. [CrossRef] [PubMed]

11. Byun, S.; Park, J.; Lee, E.; Lim, S.; Yu, J.G.; Lee, S.J.; Chen, H.; Dong, Z.; Lee, K.W.; Lee, H.J. Src kinase is a direct target of apigenin against UVB-induced skin inflammation. Carcinogenesis 2013, 34, 397-405. [CrossRef] [PubMed]

12. Zheng, J.; Hewage, S.R.; Piao, M.J.; Kang, K.A.; Han, X.; Kang, H.K.; Yoo, E.S.; Koh, Y.S.; Lee, N.H.; Ko, C.S.; et al. Photoprotective Effect of Carpomitra costata Extract against Ultraviolet B-Induced Oxidative Damage in Human Keratinocytes. J. Environ. Pathol. Toxicol. Oncol. 2016, 35, 11-28. [CrossRef] [PubMed]

13. Chou, Y.C.; Sheu, J.R.; Chung, C.L.; Chen, C.Y.; Lin, F.L.; Hsu, M.J.; Kuo, Y.H.; Hsiao, G. Nuclear-targeted inhibition of NF-kB on MMP-9 production by N-2-(4-bromophenyl) ethyl caffeamide in human monocytic cells. Chem. Biol. Interact. 2010, 184, 403-412. [CrossRef] [PubMed]

14. Hung, M.W.; Shiao, M.S.; Tsai, L.C.; Chang, G.G.; Chang, T.C. Apoptotic effect of caffeic acid phenethyl ester and its ester and amide analogues in human cervical cancer ME180 cells. Anticancer Res. 2003, 23, 4773-4780. [PubMed]

15. Chiang, H.M.; Chen, C.W.; Lin, T.Y.; Kuo, Y.H. N-phenethyl caffeamide and photodamage: Protecting skin by inhibiting type I procollagen degradation and stimulating collagen synthesis. Food Chem. Toxicol. 2014, 72C, 154-161. [CrossRef] [PubMed]

16. Kuo, Y.H.; Chen, C.W.; Chu, Y.; Lin, P.; Chiang, H.M. In Vitro and In Vivo Studies on Protective Action of N-Phenethyl Caffeamide against Photodamage of Skin. PLoS ONE 2015, 10, e0136777. [CrossRef] [PubMed]

17. Kuo, Y.-H.; Chen, C.-C.; Lin, P.; You, Y.-J.; Chiang, H.-M. N-(4-bromophenethyl) caffeamide inhibits melanogenesis by regulating AKT/glycogen synthase kinase $3 \beta /$ microphthalmia-associated transcription factor and tyrosinase-related protein 1/tyrosinase (accepted). Curr. Pharmaceutical Biotechenol. 2014, 16, 1111-1119. [CrossRef]

18. Grether-Beck, S.; Marini, A.; Jaenicke, T.; Krutmann, J. Photoprotection of human skin beyond ultraviolet radiation. Photodermatol. Photoimmunol. Photomed. 2014, 30, 167-174. [CrossRef] [PubMed]

19. Yaar, M.; Gilchrest, B.A. Photoageing: Mechanism, prevention and therapy. Br. J. Dermatol. 2007, 157, 874-887. [CrossRef] [PubMed]

20. Nichols, J.A.; Katiyar, S.K. Skin photoprotection by natural polyphenols: Anti-inflammatory, antioxidant and DNA repair mechanisms. Arch. Dermatol. Res. 2010, 302, 71-83. [CrossRef] [PubMed]

21. Bhatia, S.K.; Yetter, A.B. Correlation of visual in vitro cytotoxicity ratings of biomaterials with quantitative in vitro cell viability measurements. Cell Biol. Toxicol. 2008, 24, 315-319. [CrossRef] [PubMed]

22. Iwasawa, A.; Ayaki, M.; Niwano, Y. Cell viability score (CVS) as a good indicator of critical concentration of benzalkonium chloride for toxicity in cultured ocular surface cell lines. Regul. Toxicol. Pharmacol. 2013, 66, 177-183. [CrossRef] [PubMed]

23. Wolfle, U.; Esser, P.R.; Simon-Haarhaus, B.; Martin, S.F.; Lademann, J.; Schempp, C.M. UVB-induced DNA damage, generation of reactive oxygen species, and inflammation are effectively attenuated by the flavonoid luteolin in vitro and in vivo. Free Radic. Biol. Med. 2011, 50, 1081-1093. [CrossRef] [PubMed]

24. Aoki, R.; Aoki-Yoshida, A.; Suzuki, C.; Takayama, Y. Protective effect of indole-3-pyruvate against ultraviolet b-induced damage to cultured HaCaT keratinocytes and the skin of hairless mice. PLoS ONE 2014, 9, e96804. [CrossRef] [PubMed]

25. Gasparrini, M.; Forbes-Hernandez, T.Y.; Afrin, S.; Reboredo-Rodriguez, P.; Cianciosi, D.; Mezzetti, B.; Quiles, J.L.; Bompadre, S.; Battino, M.; Giampieri, F. Strawberry-Based Cosmetic Formulations Protect Human Dermal Fibroblasts against UVA-Induced Damage. Nutrients 2017, 9, 605. [CrossRef] [PubMed]

26. Wu, P.Y.; Huang, C.C.; Chu, Y.; Huang, Y.H.; Lin, P.; Liu, Y.H.; Wen, K.C.; Lin, C.Y.; Hsu, M.C.; Chiang, H.M. Alleviation of Ultraviolet B-Induced Photodamage by Coffea arabica Extract in Human Skin Fibroblasts and Hairless Mouse Skin. Int. J. Mol. Sci. 2017, 18, 782. [CrossRef] [PubMed]

27. Kim, J.K.; Mun, S.; Kim, M.S.; Kim, M.B.; Sa, B.K.; Hwang, J.K. 5,7-Dimethoxyflavone, an activator of $\operatorname{PPAR} \alpha / \gamma$, inhibits UVB-induced MMP expression in human skin fibroblast cells. Exp. Dermatol. 2012, 21, 211-216. [CrossRef] [PubMed] 
28. Lee, J.K.; Ko, S.H.; Ye, S.K.; Chung, M.H. 8-Oxo-2'-deoxyguanosine ameliorates UVB-induced skin damage in hairless mice by scavenging reactive oxygen species and inhibiting MMP expression. J. Dermatol. Sci. 2013, 70, 49-57. [CrossRef] [PubMed]

29. Ivan, A.L.; Campanini, M.Z.; Martinez, R.M.; Ferreira, V.S.; Steffen, V.S.; Vicentini, F.T.; Vilela, F.M.; Martins, F.S.; Zarpelon, A.C.; Cunha, T.M.; et al. Pyrrolidine dithiocarbamate inhibits UVB-induced skin inflammation and oxidative stress in hairless mice and exhibits antioxidant activity in vitro. J. Photochem. Photobiol. B Biol. 2014, 138, 124-133. [CrossRef] [PubMed]

30. Martinez, R.M.; Pinho-Ribeiro, F.A.; Steffen, V.S.; Caviglione, C.V.; Vignoli, J.A.; Barbosa, D.S.; Baracat, M.M.; Georgetti, S.R.; Verri, W.A., Jr.; Casagrande, R. Naringenin Inhibits UVB Irradiation-Induced Inflammation and Oxidative Stress in the Skin of Hairless Mice. J. Nat. Prod. 2015, 78, 1647-1655. [CrossRef] [PubMed]

31. Chiao, C.; Carothers, A.M.; Grunberger, D.; Solomon, G.; Preston, G.A.; Barrett, J.C. Apoptosis and altered redox state induced by caffeic acid phenethyl ester (CAPE) in transformed rat fibroblast cells. Cancer Res. 1995, 55, 3576-3583. [PubMed]

32. Bickers, D.R.; Athar, M. Oxidative stress in the pathogenesis of skin disease. J. Investig. Dermatol. 2006, 126, 2565-2575. [CrossRef] [PubMed]

33. Hong, M.J.; Ko, E.B.; Park, S.K.; Chang, M.S. Inhibitory effect of Astragalus membranaceus root on matrix metalloproteinase-1 collagenase expression and procollagen destruction in ultraviolet B-irradiated human dermal fibroblasts by suppressing nuclear factor k-B activity. J. Pharm. Pharmacol. 2013, 65, 142-148. [CrossRef] [PubMed]

34. Karthikeyan, R.; Kanimozhi, G.; Prasad, N.R.; Agilan, B.; Ganesan, M.; Mohana, S.; Srithar, G. 7-Hydroxycoumarin prevents UVB-induced activation of NF- $\mathrm{kB}$ and subsequent overexpression of matrix metalloproteinases and inflammatory markers in human dermal fibroblast cells. J. Photochem. Photobiol. B Biol. 2016, 161, 170-176. [CrossRef] [PubMed]

35. Zulfiker, A.H.; Hashimi, S.M.; Qi, J.; Grice, I.D.; Wei, M.Q. Aqueous and Ethanol Extracts of Australian Cane Toad Skins Suppress Pro-Inflammatory Cytokine Secretion in U937 Cells via NF-kappaB Signaling Pathway. J. Cell. Biochem. 2016, 117, 2769-2780. [CrossRef] [PubMed]

36. Kim, J.; Kim, M.B.; Yun, J.G.; Hwang, J.K. Protective Effects of Standardized Siegesbeckia glabrescens Extract and Its Active Compound Kirenol against UVB-Induced Photoaging through Inhibition of MAPK/NF-kappaB Pathways. J. Microbiol. Biotechnol. 2017, 27, 242-250. [CrossRef] [PubMed]

37. Clydesdale, G.J.; Dandie, G.W.; Muller, H.K. Ultraviolet light induced injury: Immunological and inflammatory effects. Immunol. Cell Biol. 2001, 79, 547-568. [CrossRef] [PubMed]

38. Oxholm, A.; Oxholm, P.; Staberg, B.; Bendtzen, K. Immunohistological detection of interleukin I-like molecules and tumour necrosis factor in human epidermis before and after UVB-irradiation in vivo. Br. J. Dermatol. 1988, 118, 369-376. [CrossRef] [PubMed]

39. Chiang, H.M.; Chan, S.Y.; Chu, Y.; Wen, K.C. Fisetin Ameliorated Photodamage by Suppressing the Mitogen-Activated Protein Kinase/Matrix Metalloproteinase Pathway and Nuclear Factor-kappaB Pathways. J. Agric. Food Chem. 2015, 63, 4551-4560. [CrossRef] [PubMed]

40. Chiang, H.M.; Chen, H.C.; Lin, T.J.; Shih, I.C.; Wen, K.C. Michelia alba extract attenuates UVB-induced expression of matrix metalloproteinases via MAP kinase pathway in human dermal fibroblasts. Food Chem. Toxicol. 2012, 50, 4260-4269. [CrossRef] [PubMed]

41. Chiang, H.M.; Lin, T.J.; Chiu, C.Y.; Chang, C.W.; Hsu, K.C.; Fan, P.C.; Wen, K.C. Coffea arabica extract and its constituents prevent photoaging by suppressing MMPs expression and MAP kinase pathway. Food Chem. Toxicol. 2011, 49, 309-318. [CrossRef] [PubMed]

42. Kim, Y.G.; Sumiyoshi, M.; Sakanaka, M.; Kimura, Y. Effects of ginseng saponins isolated from red ginseng on ultraviolet B-induced skin aging in hairless mice. Eur. J. Pharmacol. 2009, 602, 148-156. [CrossRef] [PubMed]

Sample Availability: Samples of the compounds are available from the authors. 